\title{
Anatolepis - a problematic Ordovician vertebrate reinterpreted as an arthropod
}

\author{
John S. Peel and A. K. Higgins
}

The name Anatolepis heintzi was proposed by Bockelie \& Fortey (1976) for a series of scale-bearing fragments from the Early Ordovician Valhallfonna Formation, northern $\mathrm{Ny}$ Friesland, Spitsbergen. The fragments were interpreted as the remains of heterostracan fishes - the oldest known vertebrates. A few months previously, similar fragments had been figured, but not named, by Nitecki, Gutschick \& Repetski (1975) from the Early Ordovician El Paso Group of western Texas. These authors were uncertain as to the affinities of the material at hand but noted an apparent similarity in ornamentation to merostome arthropods described by Raasch (1939) and other authors.

The geological similarity between rock types and faunas from the Early Ordovician of Ny Friesland and central East Greenland is well established (Fortey \& Bruton, 1973). It was consequently not totally surprising when preliminary processing of samples of Early Ordovician limestones from central East Greenland produced fragments of Anatolepis similar to those from Spitsbergen.

The limestone samples (GGU 236425, GGU 236426) were collected by AKH during August 1976 from the upper part of the Cape Weber Formation exposed along Narhval Sund to the south-east of Antiklinalbugt, on the south-west coast of Ella $\emptyset$, central East Greenland (by the base of the $35^{\circ}$ dip arrow on Plate X of Cowie \& Adams, 1957). The limestone was digested in acetic acid and the sieved, dried, residue separated in tetrabromoethane. The heavy fraction proved to contain a rich and diverse fauna of conodonts, inarticulate brachiopods and fragments of Anatolepis. Preliminary examination of the conodont fauna (Including scolopodids and Bergstroemognathus) suggests a Late Canadian (late Early Ordovician ) age, in accordance with that previously indicated by Cowie \& Adams (1957).

The majority of the Anatolepis fragments resemble those figured by Bockelie \& Fortey (1976), namely broken pieces of thin larger plates covered with a series of isolated or imbricated scales. A high proportion of the fragments are angular, which lead Bockelie \& Fortey to suggest that Anatolepis was probably a dorso-ventrally flattened animal.

One fragment is of importance in that it would appear to demonstrate that Anatolepis was probably an arthropod, comparable to the merostomes illustrated by Raasch (1939), as tentatively suggested by Nitecki, Gutscick \& Repetski (1975). The fragment is interpreted as a detached telson spine approximately $1.5 \mathrm{~mm}$ in length. The hollow spine tapers posteriorly, although the extremity has been broken away. The dorsal surface is arched and flattened medially; the ventral, uniformly convex. Scales are not clearly visible on the dorsal surface of the telson, although a series of imbricated, posteriorly directed, slightly protruding scales occurs along each lateral edge. Anteriorly, the dorsal margin of the telson expands rapidly, although only a fragment showing the initial dorsal component of expansion is preserved.

Similar hollow telson spines with pustulose ornamentation were figured by Raasch (1939), 
although direct comparison is difficult due to differences in preservation between Raasch's crushed material and the etched free specimens from Greenland.

The presence of the interpreted telson spine requires the rejection of the vertebrate hypothesis of Bockelie \& Fortey (1976). However, until further material has been processed, it would be premature to attempt to reassign Anatolepis more specifically than to the Arthropoda, although affinity with the merostomes seems likely.

\section{References}

Bockelie, T. \& Fortey, R. A. 1976: An early Ordovician vertebrate. Nature 260, 36-38.

Cowie, J. W. \& Adams, P. J. 1957: The geology of the Cambro-Ordovician rocks of central East Greenland. 1. Meddr Grønland 153, 1, 193 pp.

Fortey, R. A. \& Bruton, D. L. 1973: Cambrian-Ordovician rocks adjacent to Hinlopenstretet, North Ny Friesland, Spitsbergen. Bull. geol. Soc. Am. 84, 2227-2242.

Nitecki, M. H., Gutschick, R. C. \& Repetski, J. E. 1975: Phosphatic microfossils from the Ordovician of the United States. Fieldiana Geol. 35, 1, 9 pp.

Raasch, G. O. 1939: Cambrian Merostomata. Spec. Pap. geol. Soc. Am. 19, 146 pp.

\section{Basement-cover relationships and metamorphic studies in the East Greenland Caledonides $\left(72^{\circ}-74^{\circ} \mathrm{N}\right)$}

\section{A. K. Higgins, J. D. Friderichsen and T. Thyrsted}

The reconnaissance work in the metamorphic complexes of northern East Greenland begun in 1975 (Friderichsen \& Higgins, 1976) continued in 1976. Attention was concentrated on the relationships between Archaean basement gneiss complexes, middle Proterozoic medium- to high-grade metasediments, and the late Precambrian Eleonore Bay Group.

\section{Gletscherland - southern Suess Land}

Isotopic evidence from the Gletscherland complex which occupies all of Gletscherland and most of southern Suess Land (fig. 31), suggests it is largely of pre-Caledonian origin. Rex et al. (1976) have obtained two early Proterozoic isochron ages of $1740 \mathrm{~m} . \mathrm{y}$. and $1870 \mathrm{~m} . \mathrm{y}$. from Kap Hedlund at the east edge of the complex, and Rex et al. (this report) present a disturbed c. $2500 \mathrm{~m}$.y. age from Tærskeldal in the southern part of the complex. Comparisons can be made with the Flyverfjord infracrustal complex of the Scoresby Sund region, which has yielded several Archaean ages between 2345 m.y. and 3000 m.y. (Steiger \& Henriksen, 1972; Hansen et al., 1973; Rex \& Gledhill, 1974). The Gletscherland complex comprises biotite gneiss, hornblende gneiss, amphibolite bands and occasional dioritic bodies, all of which may be extensively veined or partially digested by granitic masses. 